Indonesian Journal of EFL and Linguistics

Vol. 1 No. 2, 2016

eISSN: 2503-4197, pISSN: 2527-5070

www. indonesian-efl-journal.org

DOI: http://dx.doi.org/10.21462/ijefll.v1i2.9

\title{
Top-Up Students Second Language Talk Time through Vlogs
}

\author{
Dr.Beena Anil \\ Assistant Professor, Department of English \\ SDNB Vaishnav College for Women, Chromepet, Chennai, India \\ e-mail: pbeenanil@gmail.com
}

\begin{abstract}
:
In this technological era, students need a change in everything especially in learning a subject which is considered to be a difficult one for second language learners (SLL). The advent of internet at all levels of learning in the educational arena is a boon to English teachers to improve the communicative skills of students. This paper shows how Vlog (a fusion of video and blog) to be used in an English teaching classroom to improve students' oral communication. Vlog helps students to practice English even outside the classroom, give instant teacher's feedback about their performance and can watch fellow students' performance. This paper discusses how teachers and students can very easily use vlog by understanding the computer mechanism.
\end{abstract}

Keywords: teaching English, communicative skills, Vlog, teacher- student collaboration

\section{INTRODUCTION}

Technology converts a classroom from teacher-centric to student -centric with appreciating increase level of confidence among students. English language learning is happening in the classroom for many years but in the present world, communication process is not happening effectively as in the past due to lack of focus on learning. Most of the students would not have exposure to use English outside the classroom offers a significant challenge. Apparently, in the present 
educational system, teachers focus more on syllabus completion and exam and mark- oriented preparation rather than developing the language competency of students. This passivity of learning, would lead students to possess a lack of accurate pronunciation, improper oral fluency, as a result, their level of confidence and morale would be at stake. English language can be learnt in an interesting way by listening to audio records and watching video, reading blogs, writing tweets and discussing online.

Technology can be used for teaching to create an impact on the process of learning accessibility. Technology will go hand in hand with teachers to impart quality education to the society. It helps teachers and learners to develop originality, divergent thinking, flexibility to achieve excellence in understanding and learning the second language.

\section{LITERATURE REVIEW}

There are various situation oriented ways to make students to speak English as a language. Using technology in this techno-era is an effective way to make learners to learn English academically as well as socially. Technology continues to advance, and language learning opportunities are abundant. A number of possible language learning applications have made students to explore to learn new things in various innovative ways. One such application is Vlog, which is useful for students as most of the students are mobile geeks. A vlog is a combination of video and blog (blog itself is a mix of web and $\log$ ). Blog is a forum for anyone who wants to express opinion, or share information personally or socially. Blogs can be used for writing and Vlog can be used for communication. Second language learners use vlogs to register their voice and ideas digitally, apparently, they monitor, evaluate their skills willingly for their better language learning.

Second language learner interacted constructively with the learning environment, both internal (Murphy 1989) and external (Stern 1983). The external environment could be considered to be the learning atmosphere. The internal environment included the learner's knowledge about language, including cognitive experiential level, belief and values, affective states, cultural background etc., which contributed to language learning as a 'hermeneutical' experience (Murphy 1989).

Brinton (2001) supposed that media tools serve as an important motivator in the language teaching process because "media materials can lend authenticity to the classroom situation, reinforcing for students the direct relation between the language classroom and the outside world" (p. 461).

Froehlich (1999) affirms the positive effects of visuals to people, which is also true of present learners:

'Most people prefer and respond more favorably to visual stimuli than to sound only. The learning process today is characterized by being informed and entertained simultaneously through a combination of complementary, easily absorbable signals to our senses... Foreign language education nowadays has to be fun.' (pp. 150-151). 
Technology has influenced language learning process and integrated the development of second language teaching and learning (Benson and Reinders 2011). Researchers like Throne and Black (2011) observe, an advantageous number of educators support for a need to develop a better learning atmosphere in online learning process. Using Vlogs in the language learning would enhance the speaking skills of learners sufficiently. While using vlogs, learners discuss various topics which would lead to team building and contribute to have virtual collaborative conversational interaction (Bryant 2006).

Dornyei (2009) has made a link between motivation and 'positive' anxiety which would generate a motivational a self- system of learning to learners towards the L2. There is a growing self-awareness, in relation among learners to others in the language learning process. Miller (2003) has observed that L2 learners have the experience of being discriminated due to their 'lack of required' language competency by their classmates and that would lead to have a negative self-image as the result, their motivation to learn the language can be decreased.

Technology enriches teachers to bring a multisensory experience to the classroom by incorporating audios and videos. It also supports teachers to design teaching materials according to the background of the cultural and linguistic diversity of learners (Lama 2006). The technology assisted teaching should aim to promote both higher order skills and lower order skills (Scrivener 2007).

Communication is still a predominant part in English language teaching that could happen only through interaction. Walsh (2002) and Myhill (2006) identified that good number of interactional features in the classrooms would develop good quality of teaching and learning language practices. Emery (2012) suggests that many current teachers of second language learners have had little substantial overall repertoire of classroom activities that are appropriate for teaching English as a second language.

This study attempts to examine students' opinion about using Vlog and computer based learning program to improve their communicative skills. Since the computer based tasks are not generally used in traditional paper-based classrooms, the students' exposure and attitude towards technology would initiate them to use Vlog in their second language learning process. This paper further discusses how Vlog is helpful to learners improve their societal influence with their fellow students and self analysis their learning methodology by the instant feedback on the vlog.

\section{RATIONALE}

Teachers create many opportunities to make students to communicate in the classroom but due to time crisis most of them are unsuccessful in the attempt. A noteworthy rationale to consider Vlog is that it boosts students speaking time. This application helps students to communicate more to improve vocabulary, to understand grammatical aspects and to erode shyness. When students start to expand the boundary of learning even outside the classroom with same liveliness with the same set of people but in a different milieu is considered to be a healthy learning approach. 
Vlog helps students to self-monitor their performance before they post their Vlog to their teacher and they can listen and do sufficient modification to their level of understanding. If the teacher feels that a student could improve in his/her presentation, a second try can be done easily.

Another benefit of using Vlog is giving feedback about students' performance. The teacher can focus or allot more time on the students' prospective vulnerable area of learning. Teacher can offer advance to students that can be viewed whenever students want to listen to and do necessary changes in the passage of practice. Students' rapport with each other and a substance of collaborative learning is positively possible.

\section{Vlogging}

Vlogging is successful, if students show mass interest in using this tool as well as their interest in developing their learning capacity. This section will review how to use vlog and various hosting web sites.

\subsection{How to Use vlog}

Vlog can be done on a Smartphone or computer- connected with a video camera and internet connection. Permit students to record their speech and upload them to the vlogs. Smartphone with VLC which is an open source that can be used unreservedly to play video clippings by using VideoLAN, 2012.

Personal computer users can download a free video software $\mathrm{NCH}$ Debut that can upload videos from a device to the NCH (a Software). While vlogging students can also add music, film clips, images and written messages to make it interesting. Personal computer users can use Window movie maker and android users can edit videos on their mobile before they upload the files..

\subsection{Video Housing Sites}

After completing the process of uploading videos, students can share their files with their friends, classmates and the teacher to receive feedback about their assignment. This procedure can be significantly done via internet, but in the case of nonavailability of internet, USB memory cards can be used. With the aid of internet, extensive and relevant websites can be utilized to upload and screen videos on the public forum.

Now a days, students are techci-savvy and update their knowledge about technology. Though whatsApp and Google primer are making ripples, Google Youtube.com is one of the most famous online video screening sites and students are fairly connect with it already. Creating an account and hosting a video on Youtube is rather an easy task for students. The only drawback is lack of privacy as anybody can view it without any restriction, but in vlog the user can make the videos private by creating an URL (Uniform Resource Locator).

Face book is another important video uploading application. Teacher can create an account for her/his class and only the members can view the contents. Such official face book can completely relate to academic interaction, so that a line can be drawn 
between students and teacher. Face book and YouTube can be easily accessible by students when they have internet connectivity to their computer.

Another online service is known as MailUV.com. This internet based service makes users to send videos to others privately which is a perfect way of adapting The predictable disadvantages are that the service will last for 10 minutes and prerecorded videos may not be used unless it is subscribed by the user. Only after subscribing, video editing can be done if not, web cameras comes in handy for editing the videos.

Smartphone applications like Whatsapp, Hiker, Roposo can be used but the limit of recording is restricted as the memory of the phone cannot store too many lengthy videos. But a small video can be shared on the group.

Another vlog hosting option is Dropbox.com. Dropbox allows users to share a minimum of 5 GB (Gigabytes) which can comprise any word document, PDF, zipped files, audio files, video files with others. Students can upload the videos or files after editing them that can be viewed by the teacher or only by the approved class mates.

\section{RESEARCH METHODOLOGY}

Vlog is helpful to students as they can be motivated and encouraged to express their views on any topic freely but within a stipulated time. Time constraint will encourage them to do in a better and comparative way. Teacher can create interesting topics or relevant questions to make students speak about it within an allotted time.. For example, questions and topics can be focused on

- A general self-introduction

- Frame questions to interview a favorite celebrity

- Review of the movie you watched recently

- A specific passage or poem can be read from the prescribed text

The objective of the study is to explore the following research questions: What are the attitudes of the respondents towards using VLOG to improve their English communicative skills?

\subsection{Setting}

The study was conducted in an arts and science colleges in Chennai, a metropolitian city in Tamil Nadu, India. Totally 60 respondents were taken for the study and they were from an Arts and Science College with English as medium of instruction. The study lasted for five months and the time allotted for instruction consisted of 60 hours. The respondents had maximum of 3 hour of instruction per week. The respondents were selected who possessed a Smartphone with internet connection or personal computer with internet connection.

\subsection{The Respondents}

The respondents in this study consisted of 60 second year under graduate students of different streams from a city Arts and Science Women's College. Based on the 
computer and Smartphone knowledge they were selected for the study. For the purpose of the present study, 60 students were selected and the demographic data about the respondents are presented in Table 1 below.

Table 1: Demographic Data about Respondents

\begin{tabular}{|l|c|c|c|}
\hline Variable & Category & F & \% \\
\hline Gender & Female & 60 & 100 \\
\hline Age & $18-19$ & 39 & 65 \\
& $20-21$ & 21 & 35 \\
\hline Educational level & Bachelor degree & 60 & 100 \\
& III semester & & 75.2 \\
\hline Duration of English & 1 to 10 years & 47 & 24.8 \\
learning & 11 to 13 years & 13 & 0 \\
\hline Engaged in VLOG & & & 100 \\
before & Yes & 0 & 00 \\
\hline Self-rated No & 60 & 10 \\
proficiency in using & Low & 00 & 90 \\
Smartphone & High & 10 & 00 \\
\hline Frequency of & Rarely & 00 & 34.8 \\
Computer usage & Sometimes & 19 & 65.2 \\
\hline
\end{tabular}

\subsection{Instruments}

To evaluate the understanding of the respondents attitude both quantitative and qualitative analysis were used. A questionnaire and a semi-structured interview on Vlog were used to analysis the given research question.

\subsubsection{Questionnaires}

Both quantitative and qualitative data have been employed for the purpose of the present study. A Demographic Information Sheet was prepared to collect the background information about the respondents. A questionnaire was designed as a part of quantitative data to establish the attitudes of students towards Vlog. Totally, the questionnaire included 18 items that were presented on a five-point Likert scale, where a lower value would specify less satisfaction and a higher value to show a greater level of satisfaction

The items in the questionnaire were checked by two academicians specialized in English Language Teaching. Before administrating the questionnaire, a pilot study was conducted with 25 students who had similar characteristics with the respondents. The 25 students were advised to fill in the questionnaire and make suggestion about the clarity and necessary changes in the items of the questionnaire. The essential changes were made before administrate it for the respondents of the study. 


\subsubsection{Interviews through $V L O G$}

Semi-structured VLOG interviews were used in the study to support the quantitative data obtained from the questionnaire. They were conducted after the study because the respondents were expected to share more of their experience regarding VLOG. All the respondents posted their interview on their Vlog and they were asked to state their opinion in English or in their native language.

\subsubsection{Internet based VLOG Program}

Vlog aims to help students to improve their English communication. In addition, users can improve on the essential grammatical components like parts of speech, modal auxiliaries. The program offers a wide range of opportunities to learn English from their fellow students under the proper guidance of a teacher. Students can share and learn vocabulary and grammatical aspects after the learning hours in the classroom. Since face book, YouTube and Whatsapp are free of subscription, students were advised to create an account on face book and register with YouTube to discuss the topics given in table 2

Table 2: The Topics

\begin{tabular}{|c|c|c|c|c|}
\hline Class & Subject & $\begin{array}{l}\text { Number } \\
\text { of } \\
\text { students }\end{array}$ & $\begin{array}{c}\text { Total } \\
\text { vlogging } \\
\text { hours }\end{array}$ & Vlog activities \\
\hline $\begin{array}{l}\text { II year B.A/ } \\
\text { B.Sc }\end{array}$ & $\begin{array}{l}\text { Foundation } \\
\text { English }\end{array}$ & 60 & $75 \mathrm{hrs}$ & $\begin{array}{l}\text { 1. Self-introduction } \\
\text { 2. Favorite subject } \\
\text { 3. Ambition in life } \\
\text { 4. Benefit of gadgets } \\
\text { 5. Childhood days } \\
\text { 6. Success } \\
\text { 7. You are a winner } \\
\text { 8. Science } \\
\text { technology and } \\
\text { 9. Education for women } \\
\text { 10. Freedom of } \\
\text { expression }\end{array}$ \\
\hline
\end{tabular}

The researcher used Dropbox folders to give students an idea of their own developmental graphs. The researcher made it clear to the respondents that the vlogging was merely used for a research study. The respondents were co operative and could find a progress in their communication

\subsection{Data Collection Procedure}

Before the study, the questionnaire was administered to the respondents for the first time. By administering the questionnaire, the researcher aimed to get an insight into the attitudes of the respondents towards Vlog, since $95 \%$ of the respondents had never experienced learning English through VLOG. The study lasted for five months and the respondents were given the opportunity to receive the feedback on 
their VLOG instantly from the researcher. After each class the researcher gave a topic to the respondents to post it on VLOG. Respondents practiced topics given by the researcher and the topics had been designed to improve their communicative skills. After the experimental study, the researcher had the opportunity of tracking the statistical data on the respondents' studies. After the sufficient exposure to VLOG, the respondents were given the same questionnaire to spot the differences in their attitudes. Semi structured interviews on VLOG were conducted by the researcher to elicit supporting information on the ideas included in the questionnaire. Answers to the questions were on the VLOG and finally, a comparison of the results of the pre and post questionnaires was performed by employing SPSS program in order to see whether there were any differences between the attitudes of the respondents before and after the study.

\section{FINDINGS}

\subsection{Quantitative Data Analysis}

An independent samples t-test was utilized to see whether there were any differences between the attitudes of students towards VLOG pertaining to age. The results showed that there were no outstanding discrepancies with regards to age, with a mean score of 3,20 for 18-19 years and 3,16 for 20-21 years $(p=0,771, t=0,29)$. Similarly, ANOVA results showed no statistical significance between the respondents' attitude towards VLOG and their educational levels, or self-rated proficiency in computer or Smartphone ( $\mathrm{p}=0,84, \mathrm{p}=0.24, \mathrm{p}=0,57$ respectively) .

Significant difference was observed between the attitudes of respondents towards VLOG before and after the study $(\mathrm{p}=0,898)$. It can be seen from the table below that the mean scores were quite different before $(M=3,19)$ and after the study $(M=3,48)$, indicating that significant changes occurred in the respondents' attitudes towards VLOG after they used it.

Table 3: Paired samples t-test for attitudes of respondents towards VLOG before and after the study

\begin{tabular}{|l|l|l|l|}
\hline Measurement & $\mathrm{N}$ & $\mathrm{X}$ & $\mathrm{S}$ \\
\hline Before the study & 60 & 3,19 &, 550 \\
\hline After the study & 60 & 3,48 & 1,06 \\
\hline
\end{tabular}

The below table 4 shows the mean scores of the questionnaire items before and after the study. One of the important points is in Item 3 stating that learning English with VLOG is hard. The response to this item proved that the mean value before $(M=3,48)$ and after $(M=3,71)$ the study developed more positive attitudes after the study. $70 \%$ respondents were of the opinion that VLOG facilitated English language learning process. Since the mean value of item 5 also increased from 3,56 to 3,80 it can be stated that respondents developed better attitudes towards VLOG after using it. 
Table 4: Mean Scores of the Questionnaire Items

\begin{tabular}{|c|c|c|c|c|c|}
\hline \multirow[t]{2}{*}{ No } & \multirow[t]{2}{*}{ Items } & \multicolumn{2}{|c|}{$\begin{array}{l}\text { Scores before the } \\
\text { Study }\end{array}$} & \multicolumn{2}{|c|}{$\begin{array}{l}\text { Scores after the } \\
\text { Study }\end{array}$} \\
\hline & & $\mathbf{M}$ & SD & $\mathbf{M}$ & SD \\
\hline 1 & $\begin{array}{l}\text { I feel more comfortable and } \\
\text { relaxed while learning English } \\
\text { with computer or Smart phone }\end{array}$ & 3,46 & 0,90 & 3,55 & 1,03 \\
\hline 2 & $\begin{array}{l}\text { The time passes quickly while } \\
\text { learning English with computers } \\
\text { or Smartphone }\end{array}$ & 3,06 & 0,70 & 3,46 & 1,16 \\
\hline 3 & $\begin{array}{l}\text { It is hard to learn English with } \\
\text { computers or Smartphone }\end{array}$ & 3,12 & 0,96 & 3,71 & 1,26 \\
\hline 4 & $\begin{array}{l}\text { My confidence increases while } \\
\text { learning English with computers } \\
\text { or smart phones }\end{array}$ & 3,10 & 0,88 & 3,69 & 1,23 \\
\hline 5 & $\begin{array}{l}\text { It is quite enjoyable to learn } \\
\text { English with computer or } \\
\text { Smartphone }\end{array}$ & 3,15 & 0,99 & 3,80 & 1,39 \\
\hline 6 & $\begin{array}{l}\text { Computers given me the } \\
\text { opportunity to learn English at } \\
\text { my own pace }\end{array}$ & 3,01 & 0,77 & 3,95 & 1,55 \\
\hline 7 & $\begin{array}{l}\text { Computer } \text { or } \text { Smartphone } \\
\text { provides me with flexibility in } \\
\text { time }\end{array}$ & 3,65 & 1,21 & 3,93 & 1,51 \\
\hline 8 & $\begin{array}{l}\text { I can practice English } \\
\text { communication more easily with } \\
\text { a computer or Smartphone }\end{array}$ & 3,41 & 1,15 & 3,50 & 1,18 \\
\hline 9 & $\begin{array}{llr}\begin{array}{l}\text { Computers } \\
\text { facilitate } \\
\text { process }\end{array} & \text { English } & \\
\end{array}$ & 3,50 & 1,18 & 3,83 & 1,40 \\
\hline 10 & $\begin{array}{l}\text { I observe better while learning } \\
\text { English with computer or } \\
\text { Smartphone }\end{array}$ & 3,23 & 1.01 & 3,38 & 1,15 \\
\hline 11 & $\begin{array}{l}\text { I have positive attitude towards } \\
\text { using computer or Smartphone to } \\
\text { learn English language }\end{array}$ & 3,26 & 1,06 & 3,25 & 1,11 \\
\hline 12 & $\begin{array}{l}\text { Computer or mobile assisted } \\
\text { language learning is more } \\
\text { motivating than traditional } \\
\text { classroom learning }\end{array}$ & 2,76 & 0,93 & 2,66 & 0,85 \\
\hline 13 & \begin{tabular}{lcc} 
Computer & \multicolumn{2}{c}{ or mobile assisted } \\
language learning is more \\
enjoyable than \\
classroom learning
\end{tabular} & 2,80 & 0,94 & 2,61 & 0,82 \\
\hline
\end{tabular}




\begin{tabular}{|c|c|c|c|c|c|}
\hline 14 & $\begin{array}{l}\text { I learn English better with } \\
\text { computers compared to the } \\
\text { traditional classroom education }\end{array}$ & 2,80 & 0,94 & 2,52 & 0,78 \\
\hline 15 & $\begin{array}{l}\text { Using computer or Smartphone is } \\
\text { more efficient than traditional } \\
\text { classroom education }\end{array}$ & 2,66 & 0,86 & 2,48 & 0,77 \\
\hline 16 & $\begin{array}{l}\text { After some time, learning } \\
\text { English language with computer } \\
\text { or Smartphone may turn out be } \\
\text { boring }\end{array}$ & 2,93 & 0,96 & 2,78 & 0,94 \\
\hline 17 & $\begin{array}{l}\text { Learning English language with } \\
\text { computers or smart phones leads } \\
\text { to an unsocial setting of learning }\end{array}$ & 2,66 & 0,86 & 2,40 & 0,75 \\
\hline 18 & $\begin{array}{l}\text { Computer assisted or mobile } \\
\text { assisted learning is not as } \\
\text { satisfying as traditional } \\
\text { classroom education }\end{array}$ & 2,75 & 0,92 & 2,40 & 0,75 \\
\hline
\end{tabular}

The mean score of Item 4 signifying that learning with computers gives confidence to the learners after the study $(M=3,26, M=3,43$ respectively). Similarly, the mean value of Item 7 augmented to 3,93 from 3,65, showing that there was a positive development in the attitudes of students towards VLOG in terms of the elasticity in time it offered. As for item 9, it can be declared that students showed more positive attitudes after the study towards the view that computers made possible in learning English.

Although the items representing positive attitudes towards VLOG had higher mean values after the study, those comparing VLOG and the conventional language learning displayed lower mean values. When the answers given to Item 13 was measured, it was pragmatic that it had a low mean value $(M=2,80)$ before the study, and after the study that mean value even reduced to 2,61. Before the study $41,6 \%$ of the students deviated with Item 14 pointing out that English language could be learnt better through computers (disagree $=38,3 \%$, strongly disagree $=3,3 \%$ ), and the percentage of students disagreeing with this item increased to 56,6\% after they used VLOG (disagree $=48,3 \%$, strongly disagree $=8,3 \%$ ). This shows that after using VLOG for some time, more than half of the students believed that they could not learn a language better via computers or Smartphone. Moreover, 48,3\% of the participants stated that VLOG was less efficient than the conservative classroom education (Item 15; disagree $=45 \%$, strongly disagree $=3,3 \%$ ), and after using VLOG, $61,7 \%$ of the students differed with that item (disagree $=51,7 \%$, strongly disagree $=10 \%)$. The mean values of the item before $(M=2,66)$ and after $(M=2,48)$ the study also replicated the difference. Another prominent transformation that occurred after the study can be seen through the results pertaining to Item 17 which was re-coded. Before the study $45 \%$ of the students said that computers created an unsocial setting of learning (disagree $=35 \%$, strongly disagree $=10 \%$ ), and after the study $58,3 \%$ of the students supported that idea (disagree $=35 \%$, strongly 
disagree $=23,3 \%$ ) and that more than half of the respondents were of the view that VLOG led to an unsocial setting of learning. The findings belonging to Item 18, comparing VLOG with conventional classroom education in terms of being acceptable indicated that before the study, $48,3 \%$ of the students did not see VLOG as satisfying as the conventional classroom education (disagree $=43,3 \%$, strongly disagree $=5 \%$ ), and it could be seen that the idea gained momentum after the study since $60 \%$ of the students stated that VLOG was not as satisfying as conservative classroom education (disagree $=38,3 \%$, strongly disagree $=21,7 \%$ ).

\subsection{Qualitative Analysis}

In this section, the results of the VLOG interview data have been analyzed. The attitudes and the use of VLOG by the respondents were tested through open-ended questions. They were asked to express their opinions about VLOG and their answers were recorded and then transcribed. The positive answers are shown in the following table.

Table 5: Validation for students' positive attitudes towards VLOG

\begin{tabular}{|c|c|c|c|c|c|}
\hline $\begin{array}{l}\text { S.n } \\
\text { o }\end{array}$ & Categories & $\begin{array}{l}\text { Number of } \\
\text { students }\end{array}$ & Mean & SD & $\begin{array}{l}\text { Total } \\
\text { numb } \\
\text { er of } \\
\text { stude } \\
\text { nts }\end{array}$ \\
\hline 1 & $\begin{array}{l}\text { A well-organized way of learning } \\
\text { English }\end{array}$ & 40 & 0.66 & 5.08 & 60 \\
\hline 2 & $\begin{array}{l}\text { Learning English through VLOG as } \\
\text { it aids and facilitates in a positive } \\
\text { way }\end{array}$ & 46 & 0.76 & 5.84 & 60 \\
\hline 3 & Learning is pleasurable & 45 & 0.75 & 5.71 & 60 \\
\hline 4 & Increases learning act & 48 & 0.80 & 6.09 & 60 \\
\hline 5 & $\begin{array}{l}\text { I understand that using Vlog is } \\
\text { motivating while learning English }\end{array}$ & 40 & 0.66 & 5.08 & 60 \\
\hline 6 & Vlog is effective and reinforcement & 43 & 0.72 & 5.46 & 60 \\
\hline 7 & $\begin{array}{l}\text { Computer/ mobile Assisted } \\
\text { Language Learning will really } \\
\text { contribute to learning English, } \\
\text { particularly to amalgamate newly } \\
\text { learned information }\end{array}$ & 53 & 0.88 & 6.73 & 60 \\
\hline 8 & $\begin{array}{l}\text { In a conventional class, one has to } \\
\text { follow a pre-settled agenda, but with } \\
\text { VLOG you get the chance to study } \\
\text { whenever you want }\end{array}$ & 45 & 0.75 & 5.71 & 60 \\
\hline 9 & $\begin{array}{l}\text { We can learn English through Vlog } \\
\text { because it facilitates to learn in } \\
\text { interesting ways }\end{array}$ & 48 & 0.80 & 6.09 & 60 \\
\hline
\end{tabular}

Indonesian Journal of EFL and Linguistics, Vol. 1 (2), 2016 


\begin{tabular}{|l|c|l|l|l|l|}
\hline 10 & Facilitates learning vocabulary & 43 & 0.72 & 5.46 & 60 \\
\hline 11 & Provides chance to redo & 56 & 0.93 & 7.11 & 60 \\
\hline
\end{tabular}

In spite of the positive aspects of Vlog presented above, the respondents had some apprehensions about using Vlog in their English learning process. These negative aspects of Vlog are given below.

Table 6: Reasons for respondents' negative attitudes towards Vlog

\begin{tabular}{|l|l|l|l|l|l|}
\hline S. no & Categories & $\begin{array}{l}\text { Number of } \\
\text { students }\end{array}$ & mean & SD & $\begin{array}{l}\text { Total number } \\
\text { of students }\end{array}$ \\
\hline 1 & Monotony & 54 & 0.90 & 6.85 & 60 \\
\hline 2 & Difficulty in concentration & 42 & 0.70 & 5.33 & 60 \\
\hline 3 & $\begin{array}{l}\text { Being less effective } \\
\text { compared to classroom } \\
\text { learning }\end{array}$ & 56 & 0.93 & 7.11 & 60 \\
\hline 4 & Lack of interaction & 30 & 0.50 & 3.81 & 60 \\
\hline 5 & $\begin{array}{l}\text { Have some technical } \\
\text { problems }\end{array}$ & 47 & 0.78 & 0.60 & 60 \\
\hline 6 & $\begin{array}{l}\text { Challenge of access to the } \\
\text { Internet }\end{array}$ & 53 & 0.88 & 6.73 & 60 \\
\hline 7 & $\begin{array}{l}\text { Lacks adequate } \\
\text { explanations for some } \\
\text { points }\end{array}$ & 56 & 0.93 & 7.11 & 60 \\
\hline
\end{tabular}

The positive attitudes of the respondents will eclipse the negative attitudes of the respondents as Vlog was effective for learning English as a second language.

\subsection{Evaluation of English Usage in their Semi-structured Interviews on Vlog}

To test the respondents' level of English knowledge an evaluation framework was used to scrutinize the components utilized by them is explained in Table 7.

Table 7: Evaluation framework for Vlog through semi structured interview

\begin{tabular}{|l|l|}
\hline Components & Criteria \\
\hline Vocabulary & $\begin{array}{l}\text { Is the student using the correct usage of } \\
\text { Word }\end{array}$ \\
\hline Grammatical aspects & $\begin{array}{l}\text { - Is the student properly using the tense/verb? } \\
\text { - Is the student upgrading the knowledge from } \\
\text { their rectified mistakes? }\end{array}$ \\
\hline Pronunciation & \begin{tabular}{l} 
Is the student honing her/his pronunciation? \\
\hline Fluency / Accuracy
\end{tabular} \\
& $\begin{array}{l}\text { Does the student talk confidently and } \\
\text { positively? } \\
\text { Does the student speak clearly without } \\
\text { awkward pauses? }\end{array}$ \\
\hline
\end{tabular}


The above mentioned criteria were used as yardstick to evaluate the respondents speaking skill on Vlog. Using Vlog in the classroom was a rewarding experience for both the researcher and the respondents.

\section{CONCLUSION}

Vlogging is a good oral communicative application. This process is a trial and error method where students would learn from their errors with the help of a facilitator. Implementation of such applications will have technical glitches too but proper outlook will help the vlogging component much smoother. When students are wellversed in using such applications their speech quality steadily improves after a stipulated time. The output of vlog can be used measure the error occurrence and speech fluency so that students' development can be enlightened and worthy of evaluating their language competency.

Respondents in this study showed great interest and enthusiasm while using Vlog. The researcher felt that technology would motivate and encourage youngsters to learn English in a positive way. The respondents of this study were of the opinion that Vlog created an enjoyable learning atmosphere. Moreover, they felt comfortable and relaxed while using Vlog for communication. The study showed that the level of anxiety of learning the English language is reduced reasonably. The study showed that the respondents could develop their speaking skill without peer pressure. The findings of the present study revealed no significant difference among the respondents in terms of their attitudes towards Vlog and variables like age, educational level but there was significant difference in the level of attitude before and after the use of Vlog.

The questionnaire item stated that Vlog gave a chance for the respondents to learn in their own pace. The result showed that Vlog made respondents to enjoy learning English, and the instant feedback from teacher helped them to improve their speaking competency gradually.

Although the respondents had positive attitude toward using Vlog but large amount of respondents felt that the traditional face to face teaching method education for learning English was effective. Here, it is clear that this method of the respondents would because of age factor.- The respondents were in could be found for Through Vlog, various activities can be used to motivate students to share their views and ideas with others which will encourage collaborative years, if they would have used technology at a very young class they would not feel a vast difference between the traditional method and technological method of learning English as a second language. The result might be effective if this would have tried with a younger group of learners.

The study analyzed how Vlog would be helpful to students to improve their oral communication post class hours. The following recommendations are based on the findings of the study:

1. Teacher should update her technological knowledge to stay abreast with modern techno-students 
2. Introducing Vlog to students will improve their interactive ability, collaborative learning and autonomous discussion with others

3. Vlog will develop speaking skill of students

4. Vlog will develop students computational skills and help them to promote their application oriented knowledge to face real life situation

5. It encourages good rapport with fellow class mates

6. Sharing responsibilities can be developed among youngsters where in the present world all of them would be working together to achieve the common goal

\section{REFERENCES}

Benson, P. and Reinders, H. (eds) (2011). Beyond the Language Classroom. Basinstoke: Palgrave, Macmillian.

Brinton, D. M. (2001). The use of media in language teaching. In Celce-Murcia, M. (Ed.), Teaching English as a Second or Foreign Language (pp. 459-475). Boston, MA: Heinle and Heinle

Bryant, T. (2006). Using World of Warcraft and other MMORPGs to foster a targeted, social and cooperative approach toward language learning. Available at: htmp// www.academiccommons.org/commons/essay/bryant- MMORPGs-for SLA, [accessed 9/8/2016]

Dornyei, Z. (2009). The L2 Motivational Self System. In Dornyei, Z. and Ushioda, E. (eds) Motivation, Language Identity and the L2 Self. Bristol: Multilingual Matters, pp. 9-42.

Emery,H. (2012). A Global Study of Primary English Qualifications: Training and Career Development. London: British Council.

Froehlich, J. (1999). Language lab - Multimedialab - Future lab. In Hogan-Brun, G. \& Jung, U. O. H. (Ed.), Media, Multimedia Omnimedia (pp. 149-155). Peter Language publishers, Frankfurt.

Lama, D. (2006). Using ICT to support young learners who are non-native speakers of English. IATEFL Young Learner Newsletter, 26-27.

Miller, J. (2003). Audible Difference: ESL and Social Identity. Clevedon: Multilingual Matters.

Murphy, J.M. (1989). Listening in a second language: Hermeneutics and inner speech. TESOL Canada Journal. 6(2), 27-44.

Myhill,D. (2006). Talk, talk, talk: Teaching and learning in whole class discourse. Research Papers in Education, 21(1): 19-41.

NCH Software. (n.d). Debut video capture software (Computer Software). Canberra, Australia. http://www.nchsoftware.com/capture/index.html

Scrivener, J. (2007). Learning Teaching ( $2^{\text {nd }}$ edn). London: Macmillan.

Stern, H.H. (1983) Fundamental Concepts of Language Teaching. Oxford: Oxford University Press.

Throne, S.L., and Black, R.W. (2011). Identity and Interaction in Internet-mediated contexts. In Higgins, C. (ed) Identity Formation in Globalizing Contexts. New York: Mouton de Gruyter, pp. 257-278. 
VideoLAN, (2012). VLC media player (Version 2.0.1.) [Computer Software[. Paris, France. http://www.videolan.org/

Walsh, S. (2002). Construction or obstruction: Teacher talk and learner involvement in the EFL classroom. Language Teaching Research, 6 (1): 3-23. 